\title{
Immediate loading over lower prosthesis in edentulous mandibles: comparison between two types of prosthetic connection
}

\author{
Carga imediata sobre protocolos inferiores: comparação entre dois tipos de conexões protéticas
}

Marina Reis OLIVEIRA ${ }^{1}$

Ariane de Souza OLIVEIRA'

Vitor Augusto LEITE ${ }^{1}$

Marisa Aparecida Cabrini GABRIELLI ${ }^{1}$

Oriana Elara Barelli PAGANELLI ${ }^{1}$

Rubens SPIN-NETO2

Valfrido Antonio PEREIRA-FILHO'

\section{ABSTRACT}

\section{Objective}

This study evaluated two implant-abutment connection systems under immediate loading of lower prosthesis in edentulous mandibles.

\section{Methods}

Seventy-two implants placed in 18 patients were analyzed. The parameters evaluated included probing depth, stability of implants and perimplant bone loss, which were measured immediately when installing the prosthesis and after 3 and 6 months. All data underwent statistical analysis (T-Test and ANOVA, 5\% significance level).

\section{Results}

Implants with Morse cone connections showed smaller, statistically significant probing depth values for all periods (0.68/1.19/1.31), when compared to the external hexagon connections (1.08/1.52/1.64). A statistically significant difference was observed between baseline, 3 months ( $p<0.01$ for Morse cone; $p<0.001$ for external hexagon) and 6 months ( $p<0.001$ for both connections). When periods were considered there was a statistically significant difference in Implant Stability Quotient ISQ values between baseline and 6 months for both prosthetic connections.

\section{Conclusion}

Immediate loading of the lower prosthesis is a viable option for the treatment of edentulous mandibles and that the external hexagon or Morse cone connections do not interfere with the success of the implants in a short-term evaluation.

Indexing terms: Dental implantation. Dental prosthesis. Jaw edentulous.

\section{RESUMO}

Objetivo

Avaliar dois sistemas de conexões protéticas sobre carga imediata em próteses tipo protocolo em mandíbulas edêntulas.

\section{Métodos}

Setenta e dois implantes instalados em 18 pacientes foram analisados. Os parâmetros avaliados incluíram: profundidade de sondagem, estabilidade dos implantes e perda óssea periimplantar, os quais foram mensurados imediatamente após a instalação das próteses e depois de 3 e 6 meses pós-operatórios. Todos os dados foram submetidos à análise estatística (Teste T e ANOVA, ao nível de $5 \%$ de significância).

\section{Resultados}

Implantes com conexão cone Morse mostraram profundidade de sondagem estatisticamente menor em todos os períodos (0,68/1,19/1,31), quando comparado com a conexão hexágono externo $(1,08 / 1,52 / 1,64)$. Diferença estatisticamente significante foi observada entre o préoperatório imediato, 3 meses ( $p<0,01$ para cone Morse; $p<0,001$ para hexágono externo) e 6 meses ( $p<0,001$ para ambas as conexões). Quando os períodos foram considerados houve uma diferença estatisticamente significante no quociente de estabilidade do implante (ISQ) entre o pré-operatório imediata e de 6 meses para ambas as conexões protéticas.

\section{Conclusão}

A carga imediata sobre protocolos inferiores é uma opção viável para o tratamento de mandíbulas edêntulas e a conexão hexágono externo ou cone Morse não interferiram no sucesso dos implantes em um período curto de avaliação.

Termos de indexação: Implantação dentária. Prótese dentária. Arcada edêntula.

\section{INTRODUCTION}

Dental implants have been widely used due to their high success rates. However, several factors interfere with the maintenance of the perimplant bone tissue, such as: surgical trauma, load conditions, degree of precision and adjustment between components, resistance and stability of the implant/abutment interface when subjected

\footnotetext{
${ }^{1}$ Universidade Estadual Paulista Júlio de Mesquita Filho, Faculdade de Odontologia de Araraquara. Rua Humaitá, 1680, Centro, 14801-903, Araraquara, SP, Brasil. Correspondência para / Correspondence to: MR OLIVEIRA. Email: <arinareis89@hotmail.com>.

${ }^{2}$ Aarhus University, Section of Oral Radiology. Aarhus, Denmark.
} 
to loads ${ }^{1-3}$. In regard to the load conditions, it is necessary a period of 5-6 months for osseointegration of the implants in the maxilla and 3 months in the mandible. However, osseointegration with early loading is also a possibility, as shown in recent studies ${ }^{2-4}$. Initially immediate loading was mostly recommended for lower prosthesis in edentulous mandibles. It is presently used in various types of implantsupported rehabilitation, as long as there is primary stability of the implants ${ }^{5-6}$. However, the connection type and load conditions directly affect the success of implant-supported rehabilitation ${ }^{4,7-8}$.

In this respect, many studies have evaluated different types of implant/abutment connections and their effect on the perimplant tissues ${ }^{9-10}$. The main advantages of the conventional external hexagon connection are easy installation of the prosthesis, avoidance of anti-rotational movements and compatibility among different implant systems. However, this type of connection shows limited efficacy when oblique forces are applied, due to its reduced height, which can cause micro-movements, screw loosening and even fracture of the connection system ${ }^{2,11}$.

In regard to the internal connections, it show higher flexural strength and better distribution of forces in relation to external systems, thus being biomechanically more favorable ${ }^{1,8,12}$. According to Streckbein et al. ${ }^{7}$, internal connections present smaller microgaps between the implant and the abutment in relation to the external connections, which is highly desirable because the higher the space between implant and abutment, the greater the risk of biological and mechanical problems, such as failure by fatigue or perimplantitis. Morse cone connections present advantages over the previously mentioned connections by promoting higher sealing and providing greater stability. That is so because this type of connection provides close contact at the implant/abutment interface, providing greater stability3,12. The objective of this study was to compare the behavior external hexagon and Morse cone implant/abutment connection systems under immediate loading on the same biological system.

\section{METHODS}

\section{Patients}

The experimental protocol was approved by the Research Ethics Committee with humans (CEP) of the Araraquara Dental School, São Paulo State University, UNESP, under protocol number 72/2009.
The patients underwent clinical and imaging examination through panoramic radiographs. The patients who met the following criteria were selected: a) total lower edentulism; b) good bone availability of residual ridge (highest height of $11 \mathrm{~mm}$ and thickness greater than $5 \mathrm{~mm}$ ); c) type I and $\mathrm{II}^{13}$ bone tissue; and d) no systemic contraindications. Patients who followed the criteria previously established by Chiapasco et al. ${ }^{14}$ were excluded from the study.

Each patient was treated with four implants of regular diameter $(3.75 \times 11 \mathrm{~mm})$ for lower protocoltype rehabilitation with functional immediate loading in the immediate postoperative period. The implants were distributed between the mental foramens, so that the two implants on the left side of each patient had Morse cone connections, while the two implants on the right side had external hexagon prosthetic connections, following a split mouth design (Figure 1).

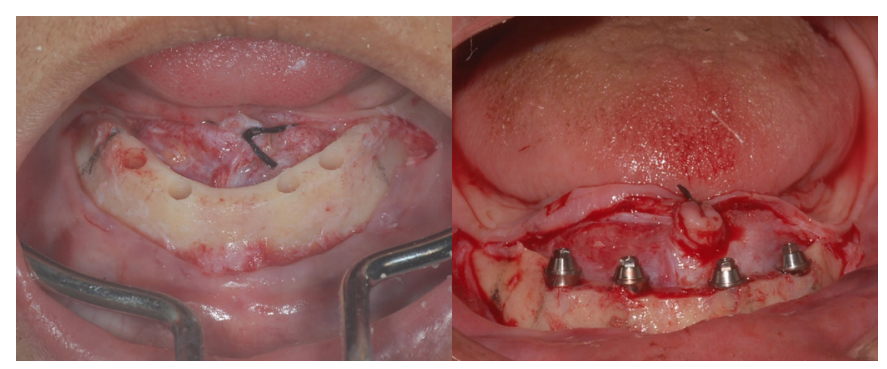

Figure 1. Dental implants installed between mentuals foramen.

\section{Surgical and prosthetic procedures}

All surgical procedures were performed under local anesthesia by the same surgeon. The implants were placed following a standardized surgical protocol and using previously prepared surgical guides. After installation of the implants, mini-abutments were adapted over them, and then transferred by molding with open molders (Figure 2).

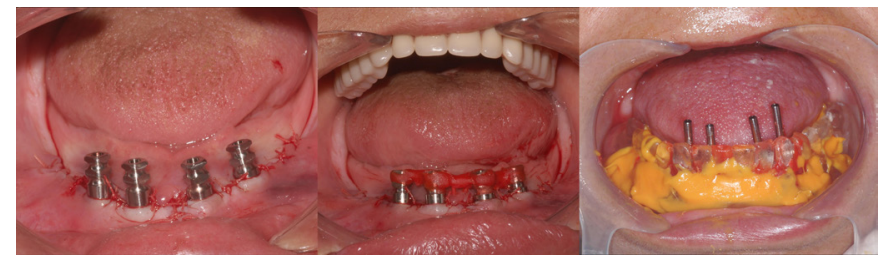

Figure 2. Adaptation of mini-piers on implants and molding with open molders.

The analogs were positioned on the transfer dies and sent to the laboratory phase. Within 72 hours, 
protocol-type hybrid prosthesis made with metal and acrylic superstructure were installed with the appropriate occlusal adjustment. All patients received also complete upper dentures (Figure 3).

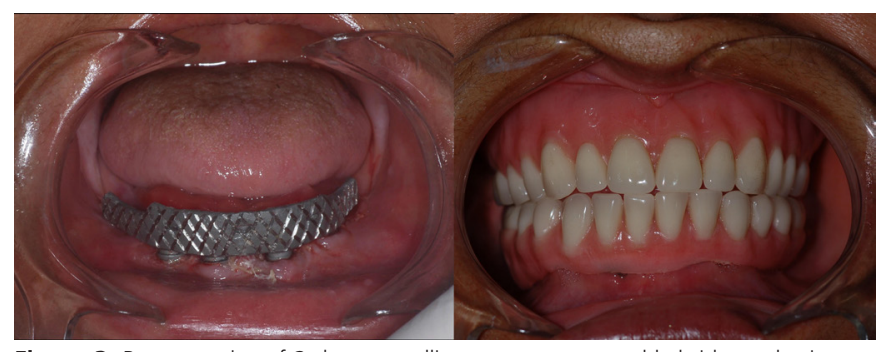

Figure 3. Postoperative of 2 days, metallic superstructure and hybrid prosthesis type protocol installed.

\section{Evaluation}

The parameters evaluated included probing depth, stability of the implants and perimplant bone loss, which were measured at the baseline (immediately after installing the prosthesis) and after 3 and 6 months postoperatively. All examinations were performed by a previously trained professional.

1. Probing depth: Evaluation of the probing depth was based on the previous clinical study by Gerber et al. ${ }^{15}$ (2009), and it was performed with a plastic millimetric periodontal probe (Colorvue ${ }^{\circledR}$ Hu-Friedy ${ }^{\circledR}$, Rotterdam, Belgium) which was positioned perpendicular to the long axis of the implant on the buccal, lingual and proximal surfaces, measuring the distance from the gingival margin to the base of the sulcus ${ }^{15}$. For each implant, probing depth $(\mathrm{mm})$ was calculated based on the average of the 4 values obtained ${ }^{16}$. For reproducibility and standardization of probe positions two devices were prepared, one for the right side and one for the left side, made from acrylic, which were adapted to the mini-abutments and contained perforations in the buccal, lingual, mesial and distal regions.

2. Perimplant bone levels: Each implant received a periapical radiograph using the parallelism technique with modified positioners and with the aid of an individualized bite block made of condensation silicone. The radiographs were scanned and the images were imported into the Adobe Photoshop CS-3 software. Brightness and contrast were standardized based on the values of the histogram of each image, which provides uniformity in shades of gray, making it easier to visualize the contours of the anatomical structures present. The images were opened one by one in the Vixwin Pro 1.2c software (Gendex-Dentsply) and enlarged on the monitor screen until they occupied the largest space possible. The tool "shades of gray" was selected in order to enable the evaluation of the numerical values of the pixels around the uppermost spirals of the implants. Analysis of spirals 1-2 was chosen as standard, in their mesial and distal surfaces, where the numerical values of the pixels for the bone tissue immediately next to each spiral were checked and recorded. The tool "shades of gray" provides the values of each pixel present in the images, ranging from 0 to 255. Near zero values are representative of bone loss areas (radiolucent image) and values close to 255 are radiopaque and represent the presence of bone tissue. Therefore, values from 0-40 were considered representative of areas without bone.

3. Stability of the implants: Implant stability was measured by resonance frequency analysis (RFA) by magnetic transduction, using Osstell ${ }^{\circledR}$ ISQ (Osstell $A B$, Göteborg, Sweden). For measuring, except for the baseline, the prosthesis was removed and SmartPeg $A 3$ was adapted to the prosthetic component. The Osstell ${ }^{\circledR}$ sensor was positioned perpendicular to the long axis of the implant in the buccolingual and mesiodistal directions. All measurements were taken in triplicate and an overall average of both axis was calculated.

The data obtained received T-Test for comparison between the two groups of prosthetic connections and analysis of variance (ANOVA) to compare the results of the periods for each prosthetic connection. The significance level used in both tests was $5 \%$.

\section{RESULTS}

The sample consisted of 18 patients ( 12 female and 6 male), totaling 72 implants inserted (36 with Morse cone and 36 with external hexagon connection). The average age of patients was 59 years. No implants were lost and no prosthetic complications were observed during the study.

\section{Probing depth}

A total of 876 measurements of probing depth were obtained, 292 for each evaluation period. In general, there was an increase in probing depth values for the two prosthetic connections according to the period, and the implants with Morse cone connections had statistically significant lower values of probing depth for all periods (0.68/1.19/1.31) when compared to implants with external 
hexagon connections (1.08/1.52/1.64) (Table 1).

As for the analysis comparing the periods for the same type of prosthetic connection, a statistically significant difference among baseline, 3 months $(p<0.01$ for Morse cone and $p<0.001$ for external hexagon) and 6 months ( $p<0.001$ for Morse cone and external hexagon) was observed (Table 2).

Table 1. Average of the parameters evaluated according to the type of prosthetic connection: T-Test at the $5 \%$ significance level.

\begin{tabular}{lcccc}
\hline Parameters & \multicolumn{2}{c}{ Prosthetic connection } & $P$ & $\begin{array}{c}\text { Number of } \\
\text { analyses }\end{array}$ \\
\hline ISQ & CM & EH & 0.38 & 432 \\
Baseline & 71.94 & 71.08 & 0.08 & 432 \\
3 months & 70.73 & 69.05 & 0.038 & 432 \\
6 months & 69.0 & 68.23 & 0.038 & \\
PD & MC & EH & & 292 \\
Baseline & 0.68 & 1.08 & $0.0015^{*}$ & 292 \\
3 months & 1.19 & 1.52 & $<0.001^{*}$ & 292 \\
6 months & 1.31 & 1.64 & $<0.001^{*}$ & 292 \\
PBL & MC & EH & & \\
Baseline & 15 & 16 & 0.61 & 272 \\
with loss & 120 & 121 & 0.61 & 272 \\
without loss & & & & \\
3 months & 29 & 33 & 0.61 & 272 \\
with loss & 107 & 103 & 0.61 & 272 \\
without loss & & & & \\
6 months & 37 & 50 & 0.61 & 272 \\
with loss & 99 & 86 & 0.61 & 272 \\
without loss & &
\end{tabular}

Note: MC: Morse Cone; EH: External Hexagon; ISQ: Implant Stability Quotient; PD: Probing Depth; PBL: Peri-implant bone loss; *: this indicates a statistically significant difference.

Table 2. Average of the parameters evaluated comparing the periods for each prosthetic connection: ANOVA at the $5 \%$ significance level.

\begin{tabular}{lccccc}
\hline Parameter & \multicolumn{2}{c}{ Periods } & & $p$ & $\begin{array}{c}\text { Number of } \\
\text { analyses }\end{array}$ \\
\hline ISQ & Baseline & 3 months & 6 months & & \\
MC & $71.94^{\mathrm{a}}$ & 70.73 & $69.0^{\mathrm{b}}$ & $0.001^{\mathrm{a}, \mathrm{b}^{*}}$ & 648 \\
EH & $71.08^{\mathrm{a}}$ & 69.05 & $68.23^{\mathrm{b}}$ & $0.004^{\mathrm{a}, \mathrm{b}^{*}}$ & 648 \\
\hline PD & & & & & \\
MC & $0.68^{\mathrm{a}}$ & $1.19^{\mathrm{b}}$ & $1.31^{\mathrm{c}}$ & $\begin{array}{l}0.01^{\mathrm{a} \mathrm{b}^{*}} \\
0.001^{\mathrm{a}, \mathrm{c}^{*}}\end{array}$ & 438 \\
EH & $1.08^{\mathrm{a}}$ & $1.52^{\mathrm{b}}$ & $1.64^{\mathrm{c}}$ & $\begin{array}{l}0.001^{\mathrm{a}, \mathrm{b}^{*}} \\
0.001^{\mathrm{a}, \mathrm{c}^{*}}\end{array}$ & 438 \\
\hline PBL & 15 & 29 & 37 & 0.051 & 816 \\
MC & 16 & 33 & 50 & 0.07 & 816 \\
EH & & & & & \\
\hline
\end{tabular}

Note: MC: Morse Cone; EH: External Hexagon; ISQ: Implant Stability Quotient; PD: Probing Depth; PBL: Peri-implant bone loss; *: this indicates a statistically significant difference.

\section{Perimplant marginal bone levels}

A total of 136 measurements per period for each one of the prosthetic connections was obtained. In the group with Morse cone connections, bone loss around the first and/or second spirals was detected in 15, 29 and 37 evaluations at the baseline, 3-month and 6-month periods, respectively. In the group with external hexagon connections bone loss was detected in 16, 33 and 50 evaluations at the baseline, 3-month and 6-month periods, respectively. However, when comparing the groups there were no statistical differences $(p<0.61)$ (table 1). Similarly, it was also not observed any statistically significant difference in the perimplant bone loss between the periods considered for either of the prosthetic connection tupes (table 2).

\section{Stability}

A total of 1296 measurements of implant stability were obtained, 432 per evaluation period and 216 for each type of connection. Considering the three study periods, there was a reduction in the ISQ values for both types of prosthetic connection. No statistical difference was observed between groups, so that for implants with Morse cone connections the values were 71.94, 70.73 and 69 for the baseline, 3-month and 6 -month periods, respectively. For implants with external hexagon connection the values were 71.08, 69.05 and 68.23 (Table 1).

In the comparative analysis of the study periods for each prosthetic connection, statistically significant differences occurred between baseline and 6 months for both types of prosthetic connection (Table 2).

\section{DISCUSSION}

The type of prosthetic connection may interfere with the results of implant-supported rehabilitation ${ }^{3,12}$. The different types of connection have their specific characteristics and it is worth noting that the greater the gap between the implant and the abutment, the greater the bacterial colonization, fatigue and risk of fracture. Those factors directly affect the surrounding bone tissue, causing resorption and even leading to the loss of the implant. Some studies show that the internal connections have a smaller space between the implant and the abutment and thus lower risk of biological and mechanical problems ${ }^{7,16-18}$. As in this study, in order to determine which implant system causes less damage to the perimplant tissues, some studies compared the different types of prosthetic connections ${ }^{7,19}$.

D'ercole et al. ${ }^{19}$ compared Morse cone and 
internal hexagon connections for bacterial infiltration at the implant/abutment interface and found no statistical differences between them. However, numerically lower bacterial infiltration was observed in the Morse cone group $^{19}$. In the present study, statistical difference was only observed between the groups for the parameter probing depth, with lower values for the Morse cone connection. For the other parameters assessed no statistical differences were observed between the two types of prosthetic connections.

The internal connections, especially the Morse cone, have shown better performance over the external connections in some experimental studies 1,3,10,17-18. Goiato et al. ${ }^{3}$, showed better distribution of loads on implants with Morse cone connections when compared to external hexagon connections. The superior results of internal over external connections may be primarily due to the lower vertical force transmitted from the bottom of the implant to the abutment, distribution of the lateral load into the implant and large contact surface between the implant and the abutment present in the internal connections ${ }^{3}$. In accordance, the present results showed lower probing values for implants with Morse cone connection when compared to the external hexagon.

Maintenance of perimplant bone crest height is very important for the success of dental implants ${ }^{9-10}$. For Albrektsson et al. ${ }^{20}$, a bone loss of up to $1.5 \mathrm{~mm}$ in the first year followed by $0.2 \mathrm{~mm}$ every year is acceptable for a successful implant. Assuming that the type of prosthetic connection interferes with the dispersion of loads around the implant, it also influences the perimplant bone loss. Therefore, several authors evaluate the perimplant bone loss in different types of prosthetic connections ${ }^{13,7-8,17-18}$. In this study, the largest amount of bone loss was observed for the external hexagon group in comparison to the Morse cone group, but without statistically significant difference between them. Similarly, Lin et al. ${ }^{9}$, evaluated the marginal bone loss on radiographs of implants with external hexagon, internal hexagon and Morse cone prosthetic connections and no statistically significant difference was observed. These results indicate that there seems to be no difference in marginal bone loss around implants with different prosthetic connections in a short period of follow-up.

In contrast, Koo et al. ${ }^{10}$ evaluated the linear bone change, dimensional bone change and the angle between the implant and the adjacent bone through radiographs and found significantly higher bone loss in implants with external connections over those with internal connections. Galindo-Moreno et al. ${ }^{21}$ also found significantly higher marginal bone loss in implants with external connection (0.714 $\mathrm{mm} /$ year) as compared to implants with internal connection $(0.516 \mathrm{~mm} /$ year) installed in the mandible after 6 and 18 months. However, as in the present study, other authors found no statistical difference in bone loss around implants with internal and external connections ${ }^{6,9}$. Thus, it is observed that the action of different types of connections on the perimplant bone resorption is a controversial subject in the literature and requires further studies and longer follow-ups for better clarification.

With regard to the load conditions, according to Ghanavati et al. ${ }^{22}$, success rate of implants under early loading is approximately $93.7 \%$. Li et al. ${ }^{6}$, followed for 12 months implants installed in fully edentulous jaws subjected to immediate loading and found a higher success rate $(98.7 \%)$. In this study, we observed a $100 \%$ success rate for the short follow-up, since no loss or failure was observed. However, in the systematic literature review by Sanz-Sánchez et al. ${ }^{5}$, the authors reported a higher chance of failure $(p<0.036)$, higher bone loss $(p<0.000)$ and lower increase in the ISQ values $(p<0.001)$ for implants with immediate loading over implants with conventional loading.

In contrast, Rismanchian et al. ${ }^{4}$, evaluated the stability quotient (ISQ), bleeding on probing, pocket depth and histomorphometric assessment after 3 months of follow-up of implants inserted into dog mandibles. Regarding the amount of bone in contact with the implant, they observed larger areas for implants with early loading $(46.17 \% \pm 12.89 \%)$, without statistical difference when compared to implants with late loading $(44.4 \% \pm 10.45 \%)$. With regard to ISQ values, statistical difference was observed between implants with early loading $(71 \pm 6.35)$ compared to late loading (66.75 $\pm 11.86)$, and the highest values were observed for the implants with early loading. Rocci et al. ${ }^{23}$, in turn, compared the bone/implant contact in implants with immediate loading and early loading. The bone area in the immediate loading group (92.9\%) was higher than in the early loading group (81.4\%), but no statistical difference was observed. Similarly, Pontes et al. ${ }^{24}$, compared the bone area in contact with implants placed in different positions undergoing early or late loading and observed no significant differences. In the present 
study, the implants were subjected to immediate loading and the two types of connection presented similar ISQ values. A statistical difference in ISQ values was only found when comparing baseline and 6-month periods in both groups

\section{CONCLUSIONS}

The results suggest that immediate loading is a viable option for rehabilitation of edentulous mandibles and the type of connection did not interfere with the success of the implants in the short-tem follow-up.

\section{REFERENCES}

1. Tonella BP, Pellizzer EP, Ferraço R, Falcón-Antenucci RM, Carvalho PSP, Goiato, MC. Photoelastic analysis of cemented or screwed implant-supported prosthesis with different prothetic connections. J Oral Implantol. 2011;37:401-10. doi: 10.1563/ AAID-JOI-D-12-00200

2. Takahashi JMFK, Dayrell AC, Consani RLX, Nóbilo MAA, Henriques GE, Mesquita MF. Stress evaluation of implantabutment connections under different loading conditions: a 3D finite element study. J Oral Implantol. 2015;41:133-7. doi: 10.1563/AAID-JOI-D-11-00205

3. Goiato MC, Pesqueira AA, Falcón-Antenucci RM, Santos DM, Haddad MF, Bannwart LC, et al. Stress distribution in implantsupported prosthesis with external and internal implantabutment connections. Acta Odontol Scand. 2013;71:283-288. doi: 10.3109/00016357.2012.672823

4. Rismanchian M, Bajoghli F, Gholamreza T, Razavi M. Dental implants: early versus standard two-stage loading (Animal Study). J Oral Implantol. 2014;40(1):85-93. doi: 10.1563/AAIDJOI-D-10-00202

5. Sanz-Sánchez I, Sanz-Martín I, Figuero E, Sanz M. Clinical efficacy of immediated implant loading protocols compared to conventional loading depending on the type of the restoration: a systematic review. Clin Oral Impl Res. 2015;26(8):964-82. doi: $10.1111 / \mathrm{clr} .12428$

6. Li W, Chow J, Hui E, Lee PK, Chow R. Retrospective study on immediated functional loading of edentulous maxillas and mandibles with 690 implants up to 71 months of follow-up. J Oral Maxillofac Surg. 2009;67(12):2653-62. doi: 10.1016/j. joms.2009.07.015

7. Streckbein $P$, Streckbein RG, Wilbrand JF, Malik CY, Schaaf $H$, Howaldt HP, et al. Non-linear 3D evaluation of different oral implant-abutment connections. J Dent Res. 2012;91(12):11849. doi: $10.1177 / 0022034512463396$

8. Gracis S, Michalakis K, Vigolo P, Vult von Steyern P, Zwahlen M, Sailer I. Internal vs external connections for abutments reconstructions: a systematic review. Clin Oral

\section{Collaborators}

The nature and level of contribution where each of the authors was involved were as follows. MR OLIVEIRA and AS OLIVEIRA: collect of data; literature review, writing and submission of the manuscript. MAC GABRIELLI and R SPIN NETO, statistical analisys and assisted in the preparation of the manuscript. VA LEITE, assisted in the surgical procedures and of the documentation of the cases. OEB PAGANELLI, critical review of the writing of the manuscript and of the English version. VA PEREIRA FILHO, surgical procedure and the documentation of the cases.

Impl Res. 2012;23(suppl 6):202-16. doi: 10.1111/j.16000501.2012.02556.x

9. Lin $\mathrm{Ml}$, Shen $\mathrm{YW}$, Huang $\mathrm{HL}$, Hsu JT, Fuh $\mathrm{L}$. A retrospective study of implant-abutment connections on crestal bone level. J Dent Res. 2013:92(12 Suppl):202S-207S. doi: $10.1177 / 0022034513510322$

10. Koo KT, Lee EJ, Kim JY, Seol YJ, Han JS, Kim TI, et al. The effect of internal versus external abutment connection modes on crestal bone changes around dental implants: a radiographic analysis. J Periodontol. 2012;82(9):1104-9. doi: 10.1902/jop.2011.110456

11. Almeida DAF, Pellizzer EP, Verri FR, Santiago-Jr JF, Carvalho PS Influence of tapered and external hexagon connections on bone stresses around tilted dental implants: three-dimensional finite element method with statistical analysis. J Periodontol. 2014;85(2):261-9. doi: 10.1902/jop.2013.120713

12. Schwarz F, Hegewald A, Becker J. Impact of implant-abutment connection and positioning of the machined collar/microgap on crestal bone level: a systematic review. Clin Oral Impl Res. 2014;25(4):417-25. doi: 10.1111/clr.12215

13. Lekholm U, Zarb G. Tissue integrated protheses. Chicago: Quitenssence; 1985.

14. Chiapasco M, Gatti C, Rossi E, Haefliger W, Markwalder TH. Implant retained mandibular overdentures with imeediate loading. A retrospective multicenter study on 226 consecutive cases. Clin Oral Impl Res. 1997;8(1):48-57. doi: 10.1111/j.16000501.1997.tb00007.x

15. Gerber JA, Tan WC, Balmer TE, Salvi GE, Lang NP. Bleeding on probing and pocket probing depth in relation to probing pressure and mucosal health around oral implants. Clin Oral Impl Res. 2009;20(1):75-8. doi: 10.1111/j.1600-0501.2008.01601.x

16. Heckmann SM, Schrott A, Graef F, Wichmann MG, Weber HP Mandibular two implants telescopic overdentures. 10-year clinical and radiographical results. Clin Oral Impl Res. 2004;15(5):560-9. doi: 10.1111/j.1600-0501.2004.01064.x

17. Gehke SA, Viana MSS, Dedavid BA. Influence of bone insersion level of the implant on the fracture strength of different connection designs: an in vitro study. Clin Oral Invest. 2014;18(3):715-20. doi: 10.1007/s00784-013-1039-7 
18. Gehke AS. Importance of crown height rations in dental implants on the fracture strenght of different connection designs: an in vitro study. Clin Impl Relat Res. 2015;17(4):790-7. doi: 10.1111/ cid. 12165

19. D'ercole S, Scarano A, Perrotti V, Mulatinho J, Piattelli A, lezzi $G$, et al. Implants with internal hexagon and conical implantabutment connections: an in vitro study of the bacterial contamination. J Implantol. 2014;40(1):31-6. doi: 10.1563/ AAID-JOI-D-11-00121

20. Albrektsson T, Zarb G, Worthington P, Eriksson AR. The longterm efficacy of currently used dental implants: a review and proposed criteria of success. Int J Oral Maxillofac Implants. 1986;18(8):11-25. doi: 10.9790/0853-1608021323

21. Galindo-Moreno P, Fernández-Jiménez A, Ó Valle F, Monje A, Silvestre FJ, Juodzbalys $G$, et al. Influence of the crowm-implant connection on the preservation of the peri-implant bone. a retrospective multifactorial analysis. Int J Maxillofac Implants. 2015;30(2):384-90. doi: 10.11607/jomi.3804

22. Ghanavati F, Shayegh SS, Rahimi H, Sharifi D, Ghanavati F, Khalesseh N, et al. The effects of loading time on osseointegration and new bone formation around dental implants: a histologic and histomorphometric study in dogs. J Periodontol. 2006;77(10):1701-7. doi: 10.1902/jop.2006.050436

23. Rocci A, Martignoni M, Burgos PM, Gottlow J, Sennerby L. Histology of retrieved immediately and early loaded oxidized implants: light microscopic observations after 5 to 9 months of loading in the posterior mandible. Clin Implant Dent Relat Res. 2003;5(1):88-98. doi: 10.1111/j.1708-8208.2003.tb00020.x

24. Pontes $A E F$, Ribeiro FS, lezzi G, Pires JR, Zuza EP, Piattelli A, et al. Bone implant contact around crestal and subcrestal dental implants submitted to immediated and conventional loading. Sci World J. 2014;2014(12):1-5. doi: 10.1155/2014/606947

Received on: 22/2/2017

Final version resubmitted on: 16/5/2017

Approved on: 22/8/2017 